\title{
Psicanálise e Literatura: o complexo de Édipo em alguns contos de Dalton Travisan*
}

Tatiane Machado de Almeida

Especialista no Ensino de Língua Portuguesa e Lit. Brasileira pela UTFPR Zama Caixeta Nascentes

Mestre em Filosofia (UFPR). Psicanalista. Professor da UTFPR, campus Curitiba.

RESUMO: A intenção deste estudo é a de reunir os resultados de uma pesquisa que promoveu a relação entre a psicanálise e a literatura. Foram aplicados alguns conceitos de Sigmund Freud aos contos $O$ pai, o chefe e o rei e $O$ caçula de Dalton Trevisan. Tomando-os como objeto de análise e reconhecimento do funcionamento psíquico, utilizou-se especificamente a noção de complexo de Édipo. Sendo assim, a teoria psicanalítica é utilizada para explicar as razões de alguns aspectos da vida das personagens criadas por Trevisan.

Palavras-chave: Psicanálise, Complexo de Édipo, incesto, conto, Dalton Trevisan.

\section{INTRODUÇÃO}

Devido a grande importância dos contos de Dalton Trevisan, este estudo analisa, a partir da teoria psicanalítica, os contos $O$ pai, o chefe e o rei e $O$ caçula, a fim de desvendar características do comportamento humano de suas personagens que estão presentes na realidade do cotidiano de cada pessoa. Serão inseridos outros contos, porém, não com tanta ênfase, mas como reforço à análise dos que aqui foram tomados como objeto de investigação.

Serão analisadas as relações familiares entre pai e filho (a), mãe e filho e marido e mulher com base na concepção freudiana de complexo de Édipo. A partir dela, buscaremos compreender algumas ações das personagens e que conseqüências essas atitudes trazem para o enredo. Para nos situarmos e termos um melhor entendimento faz-se necessário uma explicação sobre a psicanálise freudiana e o surgimento da obra de Dalton Trevisan dentro do cenário literário.

O complexo de Édipo, questão que se encontra dispersa ao longo da obra de Freud, geralmente abordado com outras questões teóricas ou clínicas, foi escolhida por percebermos a ênfase dada no relacionamento entre pais e filhos nos contos, o qual pode ser entendido a partir daquele conceito psicanalítico. Este tema, grosso modo, é uma peculiar constelação de desejos amorosos que o menino sente pela mãe e a menina pelo pai. O pai torna-se o rival do menino e a mãe a rival da menina.

Dalton Trevisan é contista reconhecido nacional e internacionalmente, participante da terceira fase do modernismo, analisado por diversos estudiosos de literatura como Beta Waldman, Paulo Paes Leme, Miguel Sanches Neto, Wilson Martins, João Manuel Simões, dentre outros; porém nenhum deles fez articulações com a psicanálise, que é a finalidade deste trabalho. Os autores citados se preocupam mais com a abordagem estética e narrativa, geralmente relacionados á análise sociológica, 0 que justifica este estudo. 


\section{PSICANÁLISE E LITERATURA}

\subsection{ALGUMAS CONSIDERAÇÕES SOBRE A PSICANÁLISE}

Podemos tomar como o marco da psicanálise o ano de 1900, quando Freud publicou $A$ interpretação dos sonhos, sua obra prima. O sistema teórico de Freud explorou áreas que a psicologia tradicional excluía. "As suas formulações teóricas tratavam de forças motivadoras inconscientes, dos conflitos entre essas forças e dos efeitos desses conflitos sobre o comportamento de uma pessoa".(Schultz, 1995, p.347) Ou seja, o objetivo da psicanálise é fornecer tratamento para indivíduos portadores de distúrbios emocionais, seu objeto de estudo é o comportamento anormal e o método é a observação clínica.

Sigmund Freud nasceu em 06 de maio de 1856 em Fruberg, Marávia (hoje Pribor, na Tchecoslováquia). Um entre os oito filhos de casal de classe baixa, ele desde cedo apresentou grande capacidade intelectual. A formação de Freud, em 1873, diferente dos psicólogos tradicionais, foi em Medicina. Durante seu treinamento hospitalar, especializou-se na anatomia e nas doenças orgânicas do sistema nervoso. Nesta época ele conheceu Josef Breuer (1942-12925), clínico geral conceituado e bem sucedido, com quem passou a discutir casos de pacientes e a utilizar o método de hipnose e catarse ("cura pela conversa").Desenvolveu-se então a técnica de livre associação, em que o paciente fala livre e espontaneamente, e tem a finalidade de trazer recordações que estavam suprimidas e que originariam o comportamento anormal dos pacientes. Freud então pode verificar que muitas destas informações reprimidas envolviam questões sexuais. Freud também desenvolveu a auto-análise, dizia que com isso poderia se compreender melhor e também compreender melhor seus pacientes. Em meio a estudos e principalmente em análises em seus pacientes e em si mesmo, Freud convenceu-se de que as perturbações neuróticas manifestadas nos indivíduos originavam-se em experiências sexuais infantis.

Freud dividiu a mente humana em id, que corresponde ao inconsciente e que é a parte menos acessível da personalidade que incluem os impulsos sexuais instintivos e os recalques; o ego que se desenvolve a partir do id e serve como agente mediador entre o eu e o mundo externo, representante da razão; o superego que se desenvolve a partir de regras de conduta ditada pelos pais na infância e serve como inibidor do id.

Segundo a teoria psicanalítica freudiana do desenvolvimento da personalidade, a criança passa por uma série de estágios antes da formação da personalidade. $O$ evento de maior influência para o desenvolvimento do comportamento humano seria o complexo de Édipo. Nesse triângulo, estabelece-se uma competição, no caso de um filho homem do filho com o pai, pelo amor da mãe. Tal desarmonia é decorrência de uma tendência natural de atração pelo sexo oposto e repulsa por pessoas do mesmo sexo. 
É absolutamente normal e inevitável que a criança faça dos pais o objeto da primeira escolha amorosa. Porém a libido não permanece fixa neste primeiro objeto: posteriormente o tomará apenas como modelo, passando dele para pessoas estranhas, na ocasião da escolha definitiva. Desprender dos pais a criança torna-se, portanto uma obrigação inelutável, sob pena de graves ameaças para a função social do jovem. Durante o tempo em que a repressão promove a seleção de impulsos parciais de ordem sexual, e, mais tarde, quando a influência dos pais, principal fator da repressão, deve abrandar, cabem no trabalho educativo importantes deveres que atualmente, por certo, nem sempre são preenchidos de modo inteligente e livre de críticas. (Freud, 1976, 58-59)

O filho deseja a mãe; o pai é visto como um rival e, portanto, tem que ser combatido. Por isso, o complexo de Édipo está intimamente ligado ao complexo de castração. Em A dissolução do complexo de Édipo, Freud vai mostrar como o menino reluta em aceitar a ameaça da castração. A experiência da visão dos órgãos genitais femininos passa a ser, então, a prova definitiva da realidade da castração, evidenciando, de modo terrífico, uma verdade que ele insistia em recusar.

Freud, ao discorrer sobre o incesto, refere-se à relação totêmica, que determina a vida dos aborígines australianos. Os aborígines vivem organizados em clãs e, por sua vez, cada clã recebe o nome de seu totem. O totem escolhido, que pode ser um animal, uma planta ou um fenômeno da natureza, é considerado sagrado. Em troca do respeito do clã, o totem, segundo a crença dos aborígines, zela pela segurança da comunidade Cada clã totêmico funciona como uma família. Um garoto, por exemplo, não deve considerar apenas sua mãe biológica como mãe, mas todas as mulheres que fazem parte do clã e que, a julgar pela idade, poderiam ser sua mãe. Sendo assim, como os laços sangüíneos valem para todos do clã, todas as mulheres são proibidas a um jovem que pertença à mesma comunidade que elas. As relações sexuais e os casamentos entre pessoas do mesmo clã totêmico são punidos com a morte. Freud interpreta o sistema dos clãs totêmicos e, sobretudo, a hereditariedade do totem, como meio de evitar o incesto. $\mathrm{O}$ fato de os totens serem hereditários é extremamente importante, pois os filhos adotam o mesmo totem de sua mãe, e não de seu pai. Fora isso, as leis de convivência entre um homem, sua mãe e suas irmãs são bastante rígidas. Um deve evitar a presença e, até mesmo, o olhar do outro. Paralelamente a isso, o desejo do filho pela mãe pode ser associado à proibição do casamento e das relações sexuais entre casais que pertençam ao mesmo clã.

A psicanálise exerceu grande influência sobre a psicologia contemporânea e também em outras áreas, como as ciências sociais, as artes, a linguagem, a religião, a filosofia, a ética e a literatura. A presente monografia considera essa influência sobre a literatura, e, recorta, da psicanálise, o complexo de Édipo para analisar os contos O Pai, o Chefe, o Rei e $O$ Caçula de Dalton Trevisan.

\subsection{SITUANDO DALTON TREVISAN NO CENÁRIO LITERÁRIO}

A primeira fase Modernista (1922 a 1930) teve início com a Semana de Arte Moderna. Nesta época o Brasil vivia os últimos anos da "República Velha", ou seja, o 
período de domínio político das oligarquias ligadas aos grandes proprietários rurais.

De 1930 a 1945 o movimento modernista vive uma segunda fase, refletindo as transformações pelas quais passou o país. Foi O período das necessidades de definições e do rompimento com as estruturas do passado. Ao mesmo tempo em que se procurava o moderno, o original e o polêmico, o nacionalismo se manifestava na busca pela "língua brasileira" (a língua falada pelo povo nas ruas), valorização do índio, denúncia da realidade brasileira, etc.

O conto brasileiro, que até então se apresentava com características comuns do gênero por causa de influências dos contos europeus, sofreu grandes renovações. O precursor do conto modernista foi Adelino Magalhães com seus contos de Casos e impressões (1916), Visões, cenas e perfis (1918), e Túmulo da Vida (1920), dos quais alguns tão expressivos e característicos aos que têm sido feitos depois da Semana de Arte Moderna de 1922. Outros nomes também tiveram destaque nessa época, como Antônio de Alcântara Machado, Mario de Andrade, Ribeiro Couto, Graciliano Ramos, Murilo Rubião, etc.

A partir da terceira fase modernista destacaram-se autores como Lígia Fagundes Teles, Clarice Lispector, Oto Lara Resende, Dalton Trevisan que

(...)são verdadeiros mestres do conto moderno, manejando um vocabulário terrivelmente nítido, donos de um mundo de perdição e desengano, de personagens duma vida irreversível, duma força intrínseca, muitas vezes de chocante brutalidade, quando não de contagiante frustração, mas todos compondo uma humanidade que ficará marcando sem nenhuma dúvida nas letras contemporâneas do Brasil. (Coutinho, 1986.p.63)

Dalton Trevisan lançou e também foi o editor da revista literária Joaquim, criada na década de 40, que foi considerada um marco do modernismo no Paraná. Porém, o próprio Dalton Trevisan escreveu na décima primeira edição da revista que "O movimento de renovação inventado por JOAQUIM não tem ambições modernistas: tem ambições modernas. Os que puderem fazer a distinção entre as duas palavras saberão o que isso quer dizer" (grifos do autor).

Para José Paulo Paes, no projeto literário de Dalton Trevisan há uma dramatização de boa parte do conjunto de contradições que caracterizam a vida contemporânea; erraria quem visse no realismo de sua obra sexo explícito ou uma faca de açougueiro, ou bisturi de cirurgião. Poucas vezes foi a carne da vida cortada mais fundo. E esse feroz realismo acaba provocando no leitor uma sensação de irrealidade, de ideologia simbólica a qual não chega, porém, a configurar-se como intenção.

Dalton Trevisan escreveu mais de 25 livros, a maioria de narrativas curtas, contos, premiado com vários prêmios Jabuti. No entanto, sua vida está cercada por uma aura misteriosa, como convém a um vampiro que se preze. Afastado da mídia e avesso a entrevistas, com raríssimas fotografias do escritor, permitindo, assim, a construção de uma personagem chamada Dalton Trevisan. De qualquer maneira, seu papel é o do escritor que pretende recusar-se à representação que dele se espera.

O primeiro livro entregue ao público. Novelas Nada Exemplares (1959) reúne uma produção de duas décadas e marca a estréia do contista num âmbito nacional. As 
relações humanas, o drama de seres ilhados por restritos horizontes surge nos contos. A periferia é retratada como uma imagem em que os indivíduos estão isolados numa existência degradada. Cinco anos após, em 1964, Trevisan publica Cemitério de Elefantes, colocando em destaque histórias que, de um lado, se passam no contexto rural, com personagens à margem do mundo moderno, e, de outro, a temática urbana. Nesse livro, está o conto $O$ caçula que será analisado neste trabalho. $O$ enredo relata a história de José, filho caçula de quarenta anos que é solteiro e é sustentado pelos pais. A mãe, dona Cecília, é muito atenciosa e paciente, leva comida no quarto para o filho, pois o filho José e o pai não se falam há dez anos. Ela também "dá-lhe pequena mesada para cinema e cigarro".(Trevisan, 1984.p.14).

Na obra trevisânica são retratadas em linguagem popular a relação familiar, as tramas psicológicas e os costumes de Curitiba. Dalton também escreveu Morte na praça (1964) O Vampiro de Curitiba (1965), Mistérios de Curitiba (1968), Desastres do amor (1968), A Guerra Conjugal (1969), dentre outros. Em A Guerra conjugal (1969) está $O$ Pai, o Chefe, o Rei outro conto que terá destaque neste trabalho. Enredo simples que se passa no meio rural, fala de uma família pobre em que o pai e o filho primogênito trabalham na roça para o sustento da casa. A mãe, dona de casa, cuida dos afazeres domésticos e dos demais filhos. João já velhinho bebe cachaça e fica valente, mexe com as mocinhas e zomba de Maria, sua esposa. André, o filho mais velho, não admite que o pai zombe da mãe e o enfrenta. Na discussão André acaba atirando "no pai, no chefe, no rei". O pai "praguejou o filho e morreu".(Trevisan, 1969, p.49).

\subsection{ANÁLISE PSICANALÍTICA DOS CONTOS DE DALTON TREVISAN}

A família é uma célula social, na qual cada um tem o seu papel (lugar) e os conflitos surgem, naturalmente, devido à estreiteza dos laços afetivos e materiais que unem as pessoas que dela fazem parte. No início do conto $O$ caçula, já nos deparamos com a troca de valores que há na família narrada. "José pendura o chapéu no cabide, atira na mesa da sala a correspondência que retirou da caixa postal. Assim que ele entra no quarto...". (Trevisan, 1984, p.13), O filho José é quem faz a tarefa normalmente exercida por pais numa família, enquanto "o velho Francisco que estava à espreita, vem apanhar o jornal e a carta". (Trevisan, 1979, p.69). Percebe-se a passividade do pai diante dos fatos e da intransigência do filho caçula de quarenta anos, que há dez anos não fala com o pai.

Também não podemos deixar de mencionar o tom incestuoso presente desde o início. "A mãe bate na porta e traz o prato na bandeja. Assiste ao almoço de José, sentado na cama, (...) a mão de leve na cabeça quase calva" (p.69). Dona Cecília ainda tem o caçula como seu objeto de desejo, como se fosse um bebê quando nasce. Ela ainda mantém uma relação erótica com José. É como se mantivesse os cuidados iniciais da mãe com o bebê, da higiene corporal, cuidado que conseqüentemente estimula sensações prazerosas e que faz com que o bebê tenha a mãe como seu primeiro 
objeto de desejo. Porém José não é mais um bebê e essa cena se torna incestuosa; José já está com quarenta anos, biologicamente já é adulto. Esses tipos de agrados são de mulher para marido, almoço na cama, cafuné... Para Freud, a mulher nunca supera o fato de ser castrada e com a chegada de um bebê é como se ele substituísse o pênis que lhe falta. Mais tarde, as mulheres, diante de algum evento, cortam o fio do desejo, percebem que o filho não pode ser tudo para elas e então continuam na busca pelo objeto de gozo. Deixemos claro que esse processo é inconsciente tanto na mãe como no filho.

\begin{abstract}
O complexo de castração nas meninas inicia ao verem elas os genitais de outro sexo. De imediato percebem a diferença e deve-se admiti-lo, também a importância. (...) e se tornam vítimas da 'inveja do pênis' está deixará marcas indeléveis em seu desenvolvimento e na formação de seu caráter, não sendo superada, sequer nos casos mais favoráveis, sem um extremo dispêndio de energia psíquica. (...) o desejo de possuir um pênis é substituído pelo desejo de um bebê. Sua felicidade é grande se, esse desejo de ter um bebê se concretiza; e muito especialmente, se o bebê é um menininho que traz consigo o pênis tão profundamente desejado. (FREUD, 1976, P.154-158)
\end{abstract}

Percebemos que dona Cecília vivência ainda o complexo de Édipo, pois não se desprendeu de seu objeto de gozo e com isso manteve também o José, o último filho, preso a esse complexo. "Não sossega a velha enquanto ele (José) não chega. Muita madrugada envolve o xale na cabeça, vai brigar com o botequineiro: - O senhor é que desgraça meu filho." ( p. 16). Isso é claramente a reação de uma esposa para um marido. "Nada como um moço dentro de casa. Se entra um ladrão... O que pode um velhinho? (...) o grande Francisco não escute, ainda se acha mais homem que o filho". (p.16). Dona Cecília colocou o filho no lugar do esposo completamente. "Há dez anos expulso do quarto sagrado". (p.16). Francisco já não dorme mais com ela, a grande preocupação de dona Cecília é o filho José. Ela age a todo instante como se José fosse o esposo dela. Numa nota de rodapé acrescentada em 1920 aos escritos sobre a teoria da sexualidade, Freud diz que há casos típicos de mulheres que deixam de exibir qualquer supervalorização sexual em relação aos homens, mas dificilmente deixam de fazê-lo em relação aos próprios filhos.

Se no conto acima o incesto está velado, no conto $O$ Menino da Sua Mãe, publicado em Macho Não Ganha Flor, o incesto está explícito. Mãe e filho prendem-se por laço erótico, com a diferença de que não temos a figura do pai, o que pode ser um dos fatores que causaram esquizofrenia no filho. "O meu filho é esquizofrênico desde os 18 anos". (Trevisan, 2006, p.71). Para a Psicanálise, a maior responsável pelo desajuste no sujeito é a família, pois ela serve de base ao indivíduo, tanto para a sua integração à sociedade, quanto para a formação de seu próprio caráter. No enredo, vemos que mãe e filho chegam às vias sexuais. A mãe diz "Não sei de outra pessoa que ele tenha atacado". (idem). Ou seja, a mãe foi a única vítima sexual do filho, que provavelmente a tinha como objeto de desejo. No ato do ataque do filho encontra-se a agressividade que age como resposta à mãe por não permitir que ele se constitua sujeito do seu próprio desejo. "Xingava furioso e - mais assustador - com a voz bem baixinha. -É hoje danada do capeta. Desta não escapa". (p.73). Nessa fala percebemos 
o desespero do filho em libertar-se, nem que para isso precise matar fisicamente a mãe, já que ela não lhe permitiu constituir como sujeito do próprio desejo.

Sou pequena e fraca. Não tinha como me defender. Achei que desta vez podia me matar. Foi muito rápido. Uma cena medonha. O ataque lá no meu quarto. Eu via a novela na tevê. Não sei de onde ele veio. Entrou pelo portão ou pulou o muro, que é baixinho. (...) De repente ele estava ali. Junto da cama. Chegou e já me agarrou. (...) Olho vago - nenhum contato humano. (...) Essas coisas de gente píssica. (...) E daí fez o que bem queria. Não foi com violência, não. Mandou que tirasse a calcinha ou ele rasgava. (...) Sabia que falava sério, já tinha retalhado a blusa. (...) Sem mais palavras, penetrou. (...) Então me soltou. (...). (...) Se o teu filho é pirado, até isso você deve sofrer. Quando todos condenam, não é a mãe que perdoa sempre? E ao menos não havia perigo de engravidar, já que estava na menopausa. (Trevisan, 2006 p.72-75)

Percebemos que a mãe não fez nada para tentar reagir à atitude do filho, visto que mantém o filho na posição de objeto de gozo. E parece não perceber a gravidade da situação. "Lembro-me ter pensado: Antes eu, e não outra" (p.73). Ou seja, a mãe não cede o filho para outra mulher, ela quer prendê-lo como seu objeto de gozo. Quando perguntaram a ela quanto tempo tinha durado o ataque no quarto, ela diz "Sei não... o que... Ai, doutor. Foi todo o tempo do mundo". (p.75). Então fica claro que o incesto se concretizara naquele dia, mais que as insinuações e outros indícios: "Foi todo o tempo do mundo". (idem).

Em outro conto, Com o facão, dói, também encontramos o complexo de Édipo, porém entre pai e filhas. É o pai quem prende as filhas em seu desejo. “-Ao acordar chama as filhas. Que uma lhe lave os pés. Outra penteie o cabelo. E, todo nu, façam massagem pelo corpo. (...) Agarra e beija as mais velhas - com força e na boca." (Trevisan, 1983, p.91) Neste conto o incesto também é explícito, o pai faz das filhas mulheres para si. Numa outra fala o pai diz a respeito das filhas: "Essas eu fiz pra mim. Qualquer dia me sirvo. Filha minha para outro não engordo." (p.93).

Passemos a considerar agora o conto $O$ caçula, em que a mãe questiona José “Meu filho, por que não conversa com seu pai?" (Trevisan, 1984, p.14) E José diz “Poxa, mãe... Nunca vai aprender?" (idem). Nas reticências estaria o desejo de José em se livrar do desejo materno, é como se dissesse para mãe que ele não é mais um bebê, não precisa mais de tanta proteção e cuidado ou que o homem da casa é o pai e não ele, e que o pai é quem tem que se opor dentro de casa e ocupar seu espaço. José também diz "- estou velho demais para pedir louvado". (idem). A benção ele não pede, ela tem que ser concedida. E o pai teria que conceder. José não quer se apresentar mais como objeto de gozo da mãe por isso desafia o pai, é um pedido de socorro, de ajuda para que ele possa se libertar da alienação ao desejo materno.

Todos os demais filhos se "casaram e desertaram a família, ficou somente José". (idem). Apenas o caçula ficou preso no cordão umbilical da mãe, pois foi ele o último filho, quem substituiu 'o órgão castrado'.

(...) com a menina o complexo de castração prepara para o complexo de Édipo, em vez de destruí-lo; a menina é forçada a abandonar a ligação com sua mãe através da influência da inveja do pênis, e entra na situação edipiana como se esta fora um refúgio. (...) As meninas permanecem nele por um tempo indeterminado; destroem-no tardiamente e, ainda assim, de modo incompleto. Nessas circunstâncias, a formação do superego deve sofrer um prejuízo; não consegue atingir a intensidade e a independência, as quais lhe conferem sua importância cultural. 
Ainda no conto $O$ Caçula, "O pai persegue a coitada de dona Cecilia, verifica antes se ele não está por perto". (Trevisan, 1984, p.14) Ou seja, Francisco aceitou o fato de ser substituído pelo filho caçula. Ele não encara o filho, ele aceita ocupar lugar secundário na atenção de dona Cecília e também dentro de casa. Para o pai é mais fácil aceitar a situação do que ter que enfrentar a esposa: “- Esse rapaz, Cecília, tem jeito não". (idem). Tem jeito não, pois não é um sujeito completo. José não se tornou um sujeito completo. Para a psicanálise a criança só se torna sujeito do próprio desejo quando deixa de ser o objeto de gozo da mãe e recalca as experiências de satisfação vividas com e no corpo materno. E José ainda vive como objeto de gozo da mãe. Os desvios da vida sexual normal e sua forma normal são determinados pelas manifestações infantis. Por isso o caçula é "incapaz de ganhar a vida" (idem). Ainda está alienado no desejo materno.

circulou algum tempo de pasta, com prospecto de seguro e amostra de chocolate. Não vendeu apólice alguma, suficiente a importância da pasta preta. As amostras ele mesmo comeu.(...) Afinal ocupava-se de servicinhos para a mãe. Se the entregam um cheque para descontar, imediatamente aflito. Rapaz bem mandado. (Trevisan, 1984, p.14)

Ocupar-se com recadinhos e afligir-se com um mínimo de responsabilidade é coisa de menino, de criança. Não conseguia ter responsabilidade, não amadurecia vivia de "pequena mesada" e vestia "a roupa sovada dos irmãos". A superação ou não da fase edípica depende das três pontas do triângulo (relação entre pai, mãe e filho). Por isso, a relação familiar, com destaque especial para o complexo de Édipico, é considerada a principal responsável no desenvolvimento de comportamentos neuróticos.

(...) pais neuropáticos, inclinados via de regra a mostrar afeição excessiva, são precisamente aquele que, por seus carinhos, muito provavelmente despertarão a disposição da criança para a doença neurótica. Por coincidência, este exemplo mostra que há modos mais diretos do que a herança, através dos quais pais neuróticos podem transmitir seus distúrbios aos filhos. (FREUD, 1976, p.230)

José ainda assim era "romântico, duas vezes foi noivo". (Trevisan, 1984, p.14) Diante do primeiro noivado o pai bradou "- Onde é que esse rapaz tem a cabeça?". (Trevisan, 1984, p.14-15) Percebemos mais claramente que Francisco também participa da alienação de José. O pai vê o filho como uma criança que é incapaz de viver longe da mãe, aprender com a vida. O pai também teme a reação da mãe se o filho sair de casa. Segundo noivado com uma "prima de terceiro grau, ao jeito de dona Cecília". (p.15). A mãe fazia gosto, já que a noiva assemelhava a ela. Se fosse pra José casar, que fosse com uma mulher igual a ela. Porém "José não marcava a data e, cinco anos depois, a pobre finou do peito". (idem).

Nas festinhas de família José sentia-se injustiçado. "comparece o irmão Agenor, preferido do pai". (idem). José sente ciúmes do irmão que tem uma vida normal, casouse mantém bom relacionamento com os pais. Como refúgio da sua angústia, José sai 
para beber e retorna só de madrugada. No mesmo tom incestuoso, a mãe "traz-lhe comida" na cama, enquanto José reclama "- O menino de ouro vem aí. Dão o carro para ele. O menino querido sai de carro. E o bichão aqui não tem nada". (idem). No inconsciente dos pais, José ainda é uma criança, e por isso não pode ter tudo o que quer. Freud no texto Feminilidade explica que no desenvolvimento das teorias sexuais infantis o ciúme da criança é por um bebê recém chegado e que será amamentado e terá todos os cuidados de higienização pelo qual ele já passou e sentia prazer. A criança sente-se então destronada, nutre um ódio ciumento em relação ao novo bebê e desenvolve ressentimento contra a mãe infiel. Esse ciúme recebe constantemente novos reforços nos anos seguintes da infância. No enredo do conto, percebemos que José vê o irmão Agenor como um intruso também; mesmo Agenor sendo mais velho, é como se José visse ele como um 'recém chegado' que tem tudo o que ele queria ter, tudo o que daria prazer a ele. E o ressentimento do caçula é maior pelo pai que tem um ótimo relacionamento com o filho Agenor. "O pai espairece no jardim, braço dado com Agenor". (idem). A preferência de Francisco pelo filho Agenor, se dá devido à separação entre mãe filho.

José tem como refúgio a bebida. "Bebe durante a semana. No domingo, em cueca, peito cabeludo, folheia revista antiga e beberica leite com mel". (Trevisan, 1984, p.15-16) Sempre um contraste entre a criança e o adulto que tenta explodir em José. Beber bebida alcoólica, peito cabeludo faz alusão ao homem, ficar de cueca, folhear revistas antigas e beber leite com mel faz alusão à criança presente em José. É o conflito psíquico que José vivência devido ao tratamento que a mãe dá a ele. Inconscientemente, deseja a mãe. Logo, ao mesmo tempo em que José quer livrar-se do tratamento que a mãe lhe dá, ele também dá forças para que a mãe continue tratando-o como criança. Ele faz coisas para despertar a atenção da mãe, como uma criança que procura a todo instante ser notada.

Um adulto que tenha se tornado neurótico em virtude da insatisfação de sua libido comporta-se em sua ansiedade como uma criança: começa a assustar-se quando sozinho, isto é, quando está afastado de alguém cujo amor se sentira seguro, e busca minorar este medo através dos expedientes mais infantis. (FREUD, 1976, p.231)

Enquanto José continua em sua busca pela ajuda paterna, continua também o confronto entre pai e filho. José espera uma reação do pai, uma atitude que o liberte para ser alguém. Para provocar o pai, José dança em pensão de mulheres. O caçula "exibe-se ao sábado, no cinema, de braço dado não com uma, senão duas e três mulatas pintadas de ouro - por todas são amadas de graça". (Trevisan, 1984, p.16). Em meio a tanta rivalidade, o filho apenas queria uma reação do pai e uma libertação para ele. Diante desses desafios entre pai e filho, José busca se identificar cada dia mais com o pai; "E cada dia mais parecido com o pai, o mesmo jeito de andar de mãos cruzadas nas costas, o jeito de alisar o cabelo atrás da orelha". (idem). Essa busca pela identificação se dá pelo fato de que, segundo Freud, com a identificação, que geralmente é parcial e limitada, do filho com o pai.

O fato que leva o pai a tornar-se rival do filho começa com o triângulo edipiano. 
Esse triângulo estabelece uma competição, no caso do filho homem, do filho com o pai, pelo amor da mãe. Isso ocorre porque o filho acha que é tudo para a mãe e se faz objeto para a mãe, porém quando ele percebe que a mãe também gosta do pai, o filho se volta contra o pai. O risco do incesto é o que torna dinâmicas as relações desencadeadas no triângulo que representa o complexo edipiano. Enquanto o filho deseja a posse da mãe, o pai tenta impedir que isso aconteça, e é visto como um rival e, portanto, tem de ser combatido. Por isso, o complexo de Édipo está intimamente ligado ao complexo de castração, que faz com que o filho reprima seus desejos pela mãe. Esse último surge com o descobrimento dos órgãos sexuais femininos (vendo a mãe nua, sua irmãzinha ou uma companheira de brinquedo). Num primeiro momento o menino não aceita o que viu e prefere atribuir um pênis a quem não tem, pois eles atribuem grande valor a esse órgão. Porém, com as confirmações da falta do pênis nas meninas, ele é obrigado a acreditar na castração (período fálico em que os meninos ao brincarem com seus órgãos genitais são censurados pelos pais e ameaçados de perdêlos).

No conto $O$ Jantar, também existe o conflito edipiano entre filho e pai, suspenso pela morte da mãe: “-O aniversário da morte de sua mãe” (Trevisan, 1984, p.45). Percebemos, pelo diálogo, que pai e filho não mantêm um bom relacionamento: "A pergunta ofendeu-o tanto como um dos arrotos do pai: era filho de ninguém". (p.45). O complexo de Édipo fica explícito na seguinte frase: "Todo o filho é uma prova contra o pai" (idem). Todo o filho vê o pai como rival durante a fase do complexo de Édipo. O processo de identificação, que geralmente se instaura nessa fase, é vivenciado pela personagem Gaspar (filho), ao recusar ser como o pai: "Filho, meu filho, desiste de lutar contra mim. Há mais de mim em você que de você mesmo". (idem). A recusa do filho é uma tentativa de não aceitar sua própria identidade, é uma tentativa de descobrir como falsa a sua semelhança com o pai. Mas o que o enredo nos mostra é que o filho vai se identificando ao pai: "Se meu pai abre a boca para falar, sei as palavras que dirá, e antes do que ele. (...) Os dois alisaram a aba do chapéu, um com o gesto do outro". (p.45-46).

Já no conto, Esse Pai dos pais, o filho respeita o lugar ocupado pelo pai, mas também luta contra as semelhanças que possa haver entre eles. Perante a morte da mãe, o pai diz ao filho: "-Vamos nós dois praguejar essa maldita". (Trevisan, 1979, p.69) Mesmo o filho não desejando isso, faz para não entrar em conflito com o pai. Percebemos que não era esse o desejo do filho, pois ele diz "-Logo eu que a mãe elegia seu pobre campeão" (idem). Porém ele não poderia contrariar o pai, "-como desafiar o rei dos reis em todo seu esplendor, emasculado que fui pela sua prepotência?" (idem). Ou seja, ele não poderia contrariar o pai, até porque o pai já exercera poder sobre ele e ele era fraco perante o pai. Encontramos nesta personagem uma ambivalência: respeita o lugar ocupado pelo pai, mas sente por ele aversão; é como se fosse o amor e ódio manifestando-se juntos. Ele quer negar em si as características do pai, quer ser o seu oposto. A relação tensa entre eles transparece nas palavras do filho. O filho que "Sempre o invejei, ao rei" (p. 70). Porém "À adoração, respondeu com desdém porque 
sou gago e magro. Para ele, gordo de gargalhada sonorosa, magreza é defeito de caráter". (idem). A princípio, a criança cria uma imagem ideal da figura paterna, na qual são ressaltadas as características positivas do pai, e, por isso, o filho deseja imitá-lo para, no futuro, ser como ele. Se o conflito desencadeado com o complexo de Édipo se prolonga até a vida adulta, a imagem ideal do pai dá lugar à imagem real e, nessa imagem, o filho se reconhece. Então, surge o desejo de ser diferente do pai e, até mesmo, de matá-lo, como se, assim, o filho pudesse impedir que, no futuro, se parecesse com ele, ou como se, dessa forma, pudesse apagar as semelhanças percebidas por ele entre si e o pai. A gagueira do filho tem um valor simbólico, pois segundo a psicanálise, o recalque sempre trará uma conseqüência, ou seja, o recalcado sempre irá se manifestar de algum modo num momento outro da vida. No conto estudado, a autoridade e o egocentrismo do pai foram recalcados pelo filho durante a infância, mas manifestou-se no filho como gagueira.

Assim fui devassando o seu mistério bem guardado - de nós onze serei o mais parecido? (...) Ah, se pudesse vomitar-lhe o sobrenome, nada ter com ele: o bigodão grisalho, a careca brilhosa, o rígido com que à janela assoa-se nos dois dedos. (...) Com a morte de mamãe no mesmo dia ele morreu pra mim. Acompanhei o enterro dos dois. Está sepultado em outro caixão longe dela. (...) Não é verdade, igual a ele não sou - me acuse de tudo, uma gota de sangue coalhado na gema de ovo. Mas não igual, não a ele. Por favor, igual a ele não sou.(Trevisan, 1979, p.72)

Nessas passagens citadas acima, a personagem mostra-se totalmente avessa à imagem paterna, demonstrando, assim, que a situação de conflito, iniciada com o complexo de Édipo, se prolonga. Também percebemos que a frustração do filho em relação ao pai começa com a morte da mãe, só aí é que o filho começa a enxergar as características negativas de seu pai. Surge então o desejo de matar o pai, a figura de pai que ele havia criado. Porém, percebemos nos relatos que a figura do pai já morrera mesmo, pois o filho já adquiriu o discurso do pai, e a negação e o ódio se dão pelo fato de enxergar no pai o seu próprio eu. Diferente do conto $O$ Caçula, em que o filho continua lutando pela morte simbólica do pai.

No conto O Pai, o Chefe, o Rei, o conflito edipiano é vivido inconscientemente com o filho primogênito. Segundo Freud, para um menino, sua mãe é o primeiro objeto de amor, e assim permanece durante o complexo de Édipo e, em essência, por toda a vida dele. E por causa desse desejo inconsciente pela mãe, há a identificação com o pai.

O pai em regra tem preferência pela filha, a mãe pelo filho; a criança reage desejando o lugar do pai se é menino, o da mãe se se trata da filha. Os sentimentos nascidos destas relações entre pais e filhos não são somente de natureza positiva, de ternura, mas também negativos de hostilidade. O complexo assim formado é destinado a pronta repressão, porém continua a agir do inconsciente com intensidade e persistência. Devemos declarar que suspeitamos represente ele, com seus derivados, o complexo nuclear de cada neurose, e nos predispusemos a encontrá-lo não menos ativo em outros campos da vida mental. O mito do rei Édipo que, tendo matado o pai, tomou a mãe por mulher, é uma manifestação pouco modificada do desejo infantil, contra o qual se levantaram mais tarde, como repulsa, as barreiras do incesto. $O$ Hamelet de Shakespeare assenta sobre a mesma base, embora mais velada, do complexo do incesto. complexo de Édipo. (FREUD, 1976, p.58)

No menino, o complexo de Édipo, no qual ele deseja a mãe e gostaria de eliminar 
seu pai, por ser este um rival, faz com que o menino busque o pai como referência de homem, ou seja, o menino precisa buscar referências para formar sua subjetividade; como ele tem interesse pela mãe e a mãe tem interesse pelo pai, ele pensa em ser como o pai para que assim ele desperte o interesse da mãe. Identifica-se a ele. No conto, vemos que o pai era um "velhinho trabalhador (...) Sóbrio era manso e de boa sombra (...) embriagava-se fácil (...) ameaçava espetar os outros". (Trevisan, 1969, p.47) O filho André seguia os passos do pai: "Chegava da roça André, onde quebrou milho o dia inteiro. (...) O moço desafiado pelo pai, bebeu meio litro de cachaça". (p.48). Nesses trechos André já demonstra adquirir traços de seu rival édipico. Como o pai, André também era trabalhador e mesmo que fosse para desafiar o pai, André começa a beber cachaça. O velho bêbado tornava-se agressivo "batia a garrafa na mesa e esmurrava a parede". (Trevisan, 1969, p.48) André também em meio às discussões com pai, tornava-se também agressivo. "Repetiu o moço que não o provocasse porque era nervoso. Em seguida derrubou a cadeira e espatifou a garrafa". (Trevisan, 1969, p.49)

A criança se constitui sujeito através da relação pai e mãe, já que normalmente é com os pais que a criança passa a maior parte do tempo. Ela se faz conforme o que ouve, dentre tantos discursos um ela toma para si, conformando-se a ele. "Podemos apenas ver que a identificação esforça-se por moldar o próprio ego de uma pessoa segundo o aspecto daquele que foi tomado como modelo". (Freud, 1976, p.134) A construção do sujeito André, no conto, se dá pela identificação com o pai. A identificação acontece através do discurso do pai. "-Você é um bandido? Então quer me sangrar?" (Trevisan, 1969, p.48) André revida "-O senhor quer que eu seja um bandido?" (p. 48). E o pai diz: "-Se for homem atire. - Atire, que mata um homem". (p. 49). E o filho diz "Quer mesmo provar? Já mostro o que é ser homem (...) - Já que pediu então eu te mato". (p. 49). André vai se moldando ao discurso do pai. O pai vai detalhando o que é ser homem e André vai conformando-se a esse discurso, pois ele tem o desejo de ser um homem. André não queria matar o pai, foi o discurso paterno que o fez agir assim. O filho cumpriu o desejo do pai. "-Atirou no pai, no chefe, no rei. Não é mais ninguém". (p. 49). O pai não é mais ninguém, pois já cumpriu seu papel na família, que é a construção do filho como sujeito, então já pode "morrer". Para ficar mais claro, podemos comparar essa cena com a de uma apresentação de uma peça de teatro. Temos um auditório cheio de pessoas, uma cortina fechada e atrás da cortina mais uma quantidade de pessoas. A partir do momento em que se abrem as cortinas, as pessoas no auditório se tornam o público e as demais, no palco, se tornam artistas (atores). Terminando o espetáculo, fechadas as cortinas, todas se tornam pessoas cada qual com um trajeto diferente. Todas representam um papel, assim como as pessoas dentro da família, cada um tem o seu papel, por exemplo, o pai cumprindo seu papel de pai, morre simbolicamente. .

No conto, Em Família, há também a conformação ao discurso do pai pelo filho. O filho caçula pega a esposa na cama com outro e dispara tiros contra o carro dela. $\mathrm{O}$ pai se decepciona, pois acha que os disparos deveriam ser contra a adúltera. "O pai 
fecha-se em silêncio e ressentimento (...) O caçula esse marido manso, entrega-se à bebida. E anuncia o próximo suicídio". (Trevisan, 2005, p.78) E o pai rebate “_Você, não, filho. (...) - Não é macho para isso". (idem). O discurso do pai diz que para o filho ser macho, será preciso se matar, então "o rapaz vai até à sala de armas. (...) Enfia o cano na boca. Aperta o gatilho". (Trevisan, 2005, p.78)

Consideremos agora a personagem Maria do conto $O$ Pai, o Chefe, o Rei, sempre demonstrando medo e servidão ao marido. "Maria e os filhos iam se chegando à porta, espiando de longe, desconfiados. Trazia a gamela de água quente e, enquanto ele molhava os pés, servia o viradinho com torresmo". Freud, na Conferência XXXIII Feminilidade afirma que em geral "uma menininha é menos agressiva, desafiadora, e auto-suficiente; ela parece ter mais necessidade de obter carinho e, por esse motivo, de ser mais dependente e dócil". (p. 145). Essas características que a mulher ganha na infância, provavelmente carregam por toda a vida. Isso faz de Maria uma mulher dependente e submissa. Dona Cecilia, personagem mãe de José do conto $O$ caçula, também demonstra servidão e submissão. Porém essas características operam com mais clareza em seu relacionamento com o filho José, por exemplo, quando ela leva comida para ele no quarto, o que se subentende ser todos os dias, há mais de dez anos, já que "Dez anos que não fala com o pai e faz as refeições no quarto". (Trevisan, 1984, p.14) Ainda assim, mesmo que sucintamente, não deixa de demonstrar submissão ao marido Francisco "escondida do marido, dá-lhe pequena mesada... (...) E olha dos lados, o grande Francisco que não escute, ainda se considera...". (p.14-16).

A situação de servidão (reconhece o lugar do pai, o lugar que o pai ocupa na família) de Maria, mãe de André, é reforçada com atos dela em relação ao marido João. "a mãe comia de pé ao lado do fogão no meio da algazarra: - Epa, vaca velha!" (Trevisan, 1987, p.48) Diante dessa situação, André passa a assumir papel de homem em defesa daquela que the deu amor e atenção durante sua vida.

(...) Por todo o período de latência, as crianças aprendem a sentir pelas pessoas que as auxiliam em seu desamparo e satisfazem suas necessidades um amor que segue o modelo e é uma continuação de suas relações, como latente, com sua ama de leite.

As resultantes da escolha de objeto infantil são transmitidas para o período seguinte. (...) Seus objetivos sexuais se atenuam e agora representam o que pode ser descrito como 'corrente afetiva' da vida sexual. (...) A escolha de objeto do período puberal é obrigada a abrir mão dos objetos da infância e começar de novo como uma 'corrente sensual. Se estas duas correntes deixarem de convergir, o resultado freqüentemente é que um dos ideais da vida sexual, a concentração de todos os desejos num único objeto, será inatingível. (FREUD, 1976, p.226-229)

André não superou o complexo de Édipo ainda, portanto a ação dele para com o pai não é apenas para defender a mãe dos insultos de João. “-Pai, deixe a mãe em paz". (Trevisan, 1987, p.48) Poderíamos interpretar essa frase não só como uma atitude de defender a mãe, mas também uma atitude de querer a mãe, "deixe a mãe!" Para mim? Percebemos em suas atitudes que deseja ocupar o lugar de seu rival edípico e honrar a mãe que tanto amor Ihe deu. Segundo Freud, uma tendência à agressividade está sempre presente ao lado de um amor intenso.

O pai de André (O Pai, o Chefe, o Rei), ao contrário do pai de José (do conto $O$ caçula), reage à tentativa do filho. "O velho nega ao filho o direito de censurá-lo: - Será 
que não sou nada aqui? Que não mando na minha casa?". (Trevisan, 1987, p.48) O pai a todo instante procura mostrar seu grau de autoridade e seu lugar na família. E André continua a desafiá-lo como em um duelo de cavalheiros que buscam como prêmio a mão da donzela em casamento.

Retomando o conto $O$ Pai, $O$ Chefe, $O$ Rei na frase de André “-Ele me duvidou disse o moço - eu atirei". (Trevisan, 1987, p.49). Vemos claramente a passagem do filho, de criança, para a fase adulta (homem), com o erro da colocação do pronome obliquo "me" percebemos a fala infantil, quando a criança está aprendendo a falar, a troca de pronomes e regras gramaticais. Na fala seguinte "-Eu atirei" (idem), a colocação correta do pronome pessoal "eu" indica que ele acabou de se constituir sujeito, tornou-se homem.

O pai repete por duas vezes “- Filho meu não pode comigo". (Trevisan, 1987, p.49) O filho não pode com ele, pois o filho não pode ocupar o lugar do pai, não pode ocupar o lugar de marido da mãe e nem ser pai de si mesmo. E ainda na última fala do pai, ele desafia o filho, "Ergueu a mão fechada, praguejou o filho e morreu". (idem). Essa atitude de praguejar o filho na hora da morte é como se dissesse que, mesmo com a ausência dele, ainda assim, o filho não ocuparia o lugar do pai, pois, como já vimos, cada qual tem o seu papel dentro da família.

\section{CONSIDERAÇÕES FINAIS}

Esse estudo monográfico procurou buscar aspectos pouco visitados da obra de Dalton Trevisan, visto que os temas abordados pelo autor constituem uma enorme riqueza. Foram analisados os contos O Pai, o Chefe, o Rei e O Caçula, de Dalton sob o aspecto psicanalítico. Foi dada ênfase ao complexo de Édipo freudiano.

Na primeira etapa deste estudo foi explicado um pouco da história da psicanálise e as teorias de Freud que deram embasamento para a realização desta análise. Também foi situado o contista Dalton Trevisan no cenário literário nacional. Nesta perspectiva, entendeu-se a pertinência de tal pesquisa para o meio acadêmico dedicado aos estudos literários. Nos contos há um grande conflito de relacionamento entre pais e filhos, tendo cumprido com o objetivo geral que era justamente estabelecer articulações entre as personagens e o complexo de Édipo

Com base na teoria psicanalítica, foi possível identificar a situação edipiana como a principal causa das frustrações das personagens e como fator determinante nos destinos daqueles que protagonizam os contos de Dalton Trevisan. Partindo-se do pressuposto de que os vários temas abordados por Dalton Trevisan são inesgotáveis quando relacionados à condição humana, o presente estudo poderia ser retomado e aprofundado numa próxima pesquisa.

\section{REFERÊNCIAS}

COUTINHO, Afrânio. A Literatura no Brasil: Relações e Perspectivas/ Conclusão. Rio de 
Janeiro: José Olympio, 1986.

FREUD, Sigmund. Obras psicológicas completas. vol. VII, VIII, XVIII, XIX. Rio de Janeiro: Imago, 1976.

SANCHES NETO, Miguel Sanches. Biblioteca Trevisan. 1. ed. Curitiba: UFPR, 1996.

PAES, José Paulo. A Aventura Literária: Ensaios sobre ficção e ficções. 2. ed. São Paulo: Companhia das Letras, 1990.

SCHULTZ, Duane. Historia da psicologia moderna. 10. Ed. São Paulo: Cultrix, 1995.

SIMÕES, João Manuel. Dalton Trevisan: Périplo (com escalas) em torno de um continente. Curitiba: Fundação Cultural, (3), abril 1980.

TREVISAN, Dalton. Joaquim. Curitiba, no 11, jun.1947.

TREVISAN, Dalton. A Faca no Coração. Rio de Janeiro: Record, 1979.

A Guerra Conjugal. 9. ed. Rio de Janeiro: Record, 1987.

Cemitério de Elefantes. 7. ed. Rio de janeiro: Record, 1984.

Macho Não Ganha Flor. 1. ed. Rio de Janeiro: Record, 2006.

Meu Querido Assassino. 2. ed. Rio de Janeiro: Record, 1983.

Rita Ritinha Ritona. 1. ed. Rio de Janeiro: Record, 2005.

WALDMAN, Berta. Do vampiro ao cafajeste: uma leitura da obra de Dalton Trevisan. 1. ed. São Paulo: Hucitec, 1982.

* Monografia de conclusão do Curso de Especialização no Ensino de Língua Portuguesa e Literatura Brasileira da UTFPR, campus Curitiba, orientadada pelo Profo Zama Caixeta Nascentes 